\title{
THE PHENOMENON OF BEARISH AND BULISH IN THE INDONESIAN STOCK EXCHANGE
}

\author{
Berto Usman \\ University of Bengkulu \\ berto_usman@unib.ac.id
}

\begin{abstract}
.
Bearish and bullish pattern commonly exist in any of stock exchanges all over the world. Hereby, the volatility of price on specific stock and index will generally perform a typical comovement. This study is officially intended to reveal the existence of bearish and bullish phenomenon in Indonesia stock exchange. The technical tool used in this study was known as candlestick analysis. It is utilized to discover the inclination of price movement and the percentage of bearish and bullish shown by the index. Further, it is noted that the object of this study is Indonesia stock exchange, which is surrogated by IDX Composite (IHSG). This research finally proved that there were 61 bearish (38.85\%) and 96 time bulish (61.15\%) patterns in IDX Composite (IHSG).
\end{abstract}

Keywords: candlestick; bearish; bullish; IDX composite

\begin{abstract}
Abstrak.
Pola bearish dan bullish pada umumnya muncul di setiap pasar modal di seluruh dunia. Oleh sebab itu, volatilitas harga pada suatu saham dan indeks secara umum akan menunjukkan pergerakan yang mendasar. Kajian ini secara khusus dimaksudkan untuk mengungkapkan kehadiran fenomena bearish dan bullish di bursa efek Indonesia. Alat analisis yang digunakan pada studi ini adalah analisis candlestick. Alat ini dipergunakan untuk menemukan kecenderungan pergerakan harga serta persentase bearish dan bullish yang ditunjukkan oleh suatu saham dan indeks. Lebih lanjut, tercatat bahwa objek dalam penelitian ini merupakan Indonesia stock exchange yang diwakili oleh indeks harga saham gabungan (IHSG). Secara singkat, penelitian ini pada akhirnya membuktikan bahwa ada sebanyak 61 indikasi pola bearish (38.85\%) dan 96 kali indikasi pola bullish (61.15\%) pada indeks harga saham gabungan (IHSG)
\end{abstract}

Kata kunci: candlestick; bearish; bullish; indeks harga saham gabungan.

Diterima: 25 Mei 2016; Direvisi: 16 Agustus 2016; Disetujui: 13 September 2016 


\section{INTRODUCTION}

The current world stock exchanges have performed a various performances regarding to the volatility of either individual stock or index price movements. Investors are supposed to have a huge number of opportunities in utilizing this circumstance. In specific case, meanwhile the market experiencing down trend, most of investors are bear by the frightening of market situation. However, on the other hand some investors are doing profit-taking actions for their portfolio of investment. In this case, a comprehensive understanding with respect to the behavior of price movements is obviously needed. Therefore, more efforts in forecasting the price behavior should be done by market players in identifying the best timing of transactions.

As argued by Tandelilin (2010), forecasting stock or index price movements is commonly conducted in two ways. First, it could be done by employing fundamental analysis and second by utilizing technical analysis. Hereby, fundamental analysis refers to the utilization of specific financial information of related firms in predicting the prospects of certain company's growth in future. While, technical analysis focuses on the implementation of historical trading data and current financial news in measuring the indicators of future stock movements (Brigham \& Ehrhardt, 2005; Usman, Nurazi \& Zulkarnain, 2012; Usman \& Tandelillin, 2014; Nurazi, Kananlua \& Usman 2015; Nurazi \& Usman 2015).

Both of forecasting techniques (fundamental and technical) have empirically shown significant differences in terms of market efficiency. Many views and opinions in regard to the effectiveness of these techniques ultimately lead to the unresolved debate (Kavajech \& White, 2005; Usman, Nurazi \& Zulkarnain, 2012). The differences of Paradigms resulted from the adherents of these streams also generate pros and cons among the practitioners and academicians (Usman, 2013). In recent days, many studies are conducted to prove the effectiveness of both techniques. As noted by Brigham \& Ehrhardt (2005), most of them are based on the wide theories developed from the Efficient Market Hypothesis (EMH) and Arbitrage Pricing Theory (APT).

According to EMH theory as argued by Fama, (1991) and Fama \& French, (1992; 1993) a specific stock market can be divided into three forms; (i) market 
where its circumstance is efficient in weak form, (ii) semi-strong, and (iii) strong form. The theory of EMH suggests that in an efficient market, nobody is likely able to beat the market and earn abnormal returns above the average performance of market itself. Further, the Arbitrage Pricing Theory (APT) points out that many factors are presumably able to affect the stock price movements in a market. Those potential factors are supposed to be classified as macro and microeconomics factors (Nurazi \& Usman, 2016). Nevertheless, practitioners who take position in technical stream do not agree with this notion. Practitioners believe in that stock price movements can be predicted by using market news and historical data which is plotted on a graph. The movement patterns are the basis for practitioners to acquire the expected abnormal return, in which they make investment decisions by following the recent condition of market and identify the behavior of price movements.

In today's world, there are various number of technical analysis tools which can be used to help traders in predicting the price movements. By the end of 2012, there were at least \pm 58 types of technical tools that can be utilized by traders in observing the price movements. Also, those of technical tools are commonly employed to forecast the volume of sales, selling and buying activities on a particular stock. The usage of technical tools is adaptable to the users' needs and can be set up according the level of apprehension of users'. This is consistent with the research conducted by Lu \& Shiu, (2012) which notes that one of the technical tools that prevalently used by the most market players all around the world is candlestick analysis.

Candlestick analysis is a graphical representation that is obtained from the historical prices of certain stock or index. These data consist of information as an indicator of price movements (Marshall, Young \& Cahan, 2006; 2008). Technical indicator that is illustrated in the graph comprised of a series of data plots. It reflects the output relating to the use of formulas that is particularly applied on specific securities. The data in regard to price movements including the various combinations of opening price, high, low, and closing price within a specific time period (Usman, Nurazi \& Zulkarnain, 2012). This information is believed as the useful data in predicting the patterns and trend of price movements. The main 
pattern that should be known is whether the historical data shows upward trend, downward trend or sideways trend (Varadharajan \&Vikkaraman, 2011; Lu \& Shiu, 2012).

In the candlestick analysis, users will be faced on a belief that all information and market sentiments are depicted in the real price movements. Therefore, by observing the combination of four prices positions of a certain stock, users are able to draw a provisional conclusion relating to the next price movements (Hendra, 2008). These methods commonly used by capital market participants in order to anticipate the phenomenon of bearish and bullish (Fock, Clein \& Zwergel, 2005).

In order to identify the bullish and bearish phenomenon on either certain stock or index, users are generally employing the candlestick analysis. The fluctuation may also affect the stock movement, which is relating to investor's interest and decision, because investors tend to select the stock by considering the incoming information of specific stock and its bullish and bearish conditions. Moreover, Usman \& Tandelilin (2014) point out that the specific incoming information will be spread on two types of news, namely good and bad news. Therefore, the tendency of price movements is also generally related to the news of related-stock.

The purpose of this study is generally more practical, but it is combined with the wide range of empirical evidences. There have been seminal studies conducted to assess the effectiveness of technical analysis in stock market. In spite of this, a few studies have tried to effectively elaborate, decompose and combine the application of technical tools with the measures of economic conditions that is surrogated by the phenomenon of bearish and bullish. These conditions are generally predicted by using historical data. Based on the data used, it is plausible for traders estimating the likely trend that would be followed by the pattern of stock or index movement. In this study, the research object is IDX Composite (IHSG) movement from the year of 1997 to 2013, which consists of 817 weeks of observation. Furthermore, the identification of bearish and bullish in IDX Composite (IHSG) performed by utilizing candlestick analysis. For this reason, the analysis with respect to the prediction on stock price movement will eventually 
show the indications of phenomenon bearish and bullish. Henceforth, investors and traders can equip themselves in order not to get lost in making the decision about selling, buying or holding particular securities.

The remainder of the paper is structured into several sections. The first section is shown by the elaboration of introduction of study purposes and the usage of candlestick analysis in common stock markets. Second, a comprehensive literature review is conducted in order to expose the characteristic of candlestick analysis itself. Third, a specific research method called as add ins tool is utilized. Fourth, discussion in regard to the investigation of bearish and bullish percentage in Indonesia stock exchange is delivered. Finally in the fifth section, this study draws conclusion remarks with respect to the current condition of bearish and bullish in the employed data.

\section{METHODS}

This study is determined as a quantitative descriptive research that is based on a set numbers, and is described in a systematic analysis. The data sample is extracted from Indonesia stock exchange page, particularly in the sub of historical data menu (www.idx.co.id). Quantitative data used in this study are relating to the opening price, highest, lowest, and the closing prices of Jakarta Composite Index (IHSG) during the observation period of 17 years (1997-2013). Moreover, the process of data collection is very important in conducting the technical analysis. The obtained data in this study is completely based on the trading activity of an index, particularly in the Indonesia stock exchange, which is collecting by using weekly data of 17 years time series data observation. This study also employs the secondary data, which is obtained from various literatures and references. Furthermore, the method of data collection utilizes documentary study, in which the supporting data is obtained from the electronic media sources, company's prospectus, and through Internet. In this case, the main data is particularly collected from the official website of Indonesia Stock Exchange (www.idx.co.id).

The method used in this study utilizing an application of candlestick formula. Each price relating to primary data obviously contains a number of 
information. Given that, I used this approach as the introduction of bullish and bearish trend, which predates the emergence of a candlestick chart formation. Data processing on this analysis is based on the use of excel_adds_ins "auto pattern recommendation" as suggested by Hendra (2008). This analysis is performed directly along with an excel spreadsheet called as "hendras candle function". Moreover, the categorization of period relating to bearish and bullish phenomenon is based on the method of Fabozzi and Francis, (1979a; 1979b) (such as by averaging the value of trade relates to the event of indications, particularly the indications which are resulted in candlestick analysis). The predicted value of index, which is below the average value would be classified as bearish phenomenon. Otherwise, the value of index, which is above the average value would be classified as bullish phenomenon.

In more specific explanation, the elaboration of candlestick implementation refers to Figure 2. Here, 0 denotes the value in the cell of open price. $\mathrm{H}$ refers to the value in the cell of high price. L means as the value in the cell of low price. $\mathrm{C}$ is the value in the cell of close price. Period can be defined between 5 and 9. METHOD is defined as 2. Multiplier (MLT) is the quantity that ideally should be bigger than 1 and in this study we used 2 as the MLT values. SLT denotes as the significance of trends, and we determined 0.7 as suggested by Hendra, 2008. The following Figure 2 presents the data proceed by using the formula of Hendras_All_Candle from Microsoft excel 2010.

According to the function of arguments and results of the projected image in Figure 2, we will be directly informed the basic information relating to the indication of bullish and bearish phenomenon. Therefore, the percentage of bullish and bearish has to be calculated with the following formula:

$$
\begin{aligned}
& \text { The percentage of Bearish }=\frac{\sum \text { usish }}{\text { s. Oullish ind Bearish }} \times 100 \% \\
& \text { The percentage of Bullish }=\frac{\Sigma \text { Dull:sh }}{\text { S. Iuilish int. Dearish }} \times 100 \%
\end{aligned}
$$

Formulas 1 and 2 that can be used to obtain the percentage of indication of bearish or bullish are based on the main patterns of stock prices movement issues. Those movements can be observed from the trend shown by the candlesticks chart (Usman, Nurazi \& Zulkarnain, 2012). Further, the treatment by using 
recommended software also aims to describe the condition of index in the longterm of observation period from 1997 to 2013. For this reason, the result is expected to provide the empirical evidence about the main patterns and trends in stock trading activity in Indonesia stock exchange.

\section{RESULT AND DISCUSSION}

Candlestick analysis is applied to generate the indication of bullish and bearish in Jakarta Composite Index (IHSG). Furthermore, the utilization of formula will result in predictions about the movement of index. By using the predicted value of prices, which are generated by candlestick analysis, it is plausible for users to identify the level of comparison relating to the significance of IHSG.

Based on the analysis by using candlestick formations that is including the value of Hs_All_Candle open price, high, low, close price, period (9), multiplier (2), and SLT which is set as 0.7, I obtained the particular months which are entered into the formula of candle formation. Specifically, those candle formations are indicating the most influential situation of bullish and bearish in the observation period from 1997 to 2013. The following Figure 1 illustrates the IHSG movement patterns over period of 17 years or 817 weeks with several indications relating to upward, downward and sideways trends in IHSG.

Figure 1 shows that IHSG movement tends to be in increasing trend. In plain, it can be concluded that the main trend following the index value is upward trend (bullish pattern). Nevertheless, in the middle of 2007, it showed that the value of index drastically decreased. This suggests a phenomenon which sweptback trend on the index is bearish. This happened because Indonesia was hit by the global financial crisis that is triggered by subprime mortgage in the United States, and had impacted on trading activity in Indonesia Stock Exchange. This circumstance is also experienced by the other stock exchanges, such China stock exchange with its Shanghai composite index (SHCOMP), Singapore stock exchange with its Strait times index, and so forth. No longer after this condition, Indonesia and the other stock exchanges began to recovery. In general, we can infer that the movement of index shows positive trend. Besides, this circumstance illustrates 
that the growth of index is particularly reflected in improving economic conditions (bullish).

Figure 1. The volatility of IDX composite (IHSG)

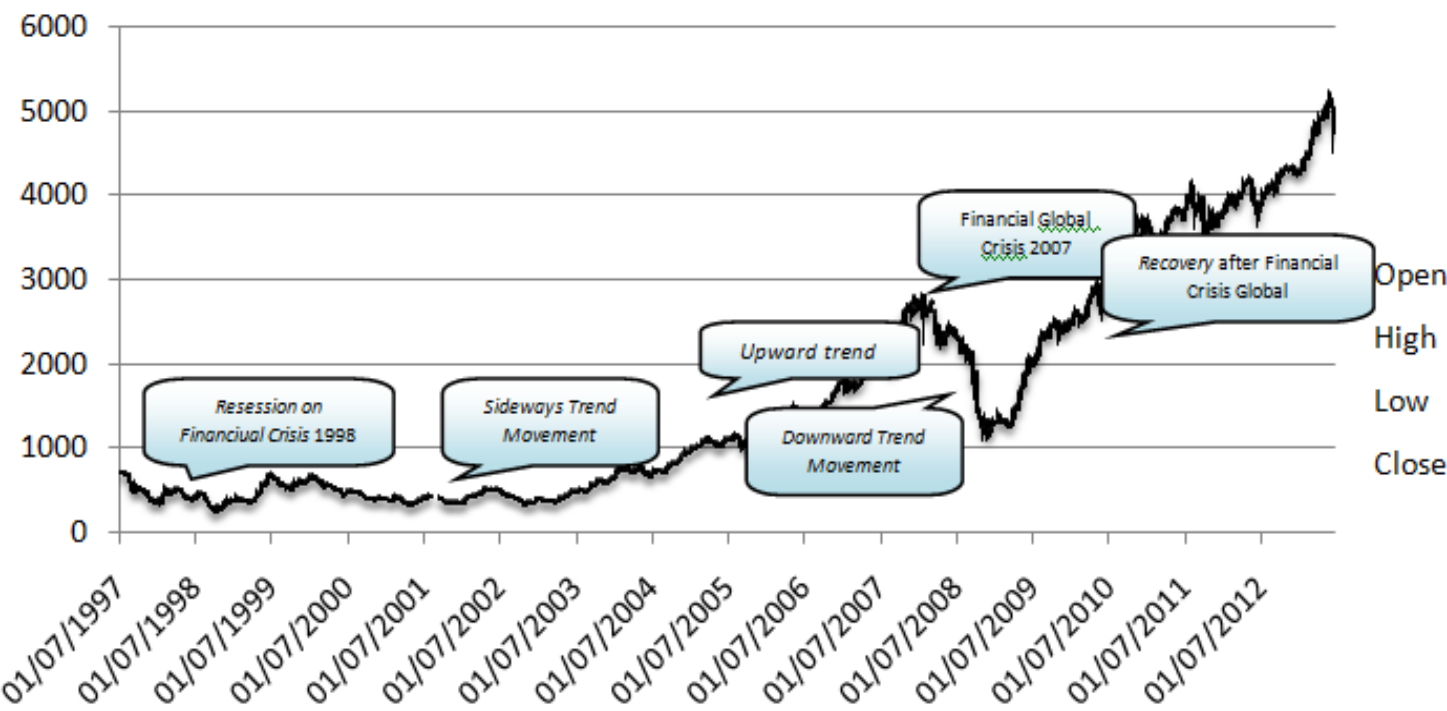

Source: The data is processed (2013).

According to the analysis of index by using "Hendras Candle function" which including the value of opening price, highest price, lowest price and closing price during the observation period from year 1997 to 2013, I acquired 157 weeks indications that indicate the occurrence of bearish and bullish. The indications of these phenomena are divided into 61 weeks of bullish and 96 weeks bearish. The accuracy regarding to these two phenomena can be calculated as can be seen in Table 1 as follows.

Table 1. Indication of bearish \& bullish by employing candlestick analysis

\begin{tabular}{cc}
\hline The number of Indications between Bearish and Bullish \\
\hline Bullish & Bearish \\
96 & 61 \\
\hline
\end{tabular}

In relation to the information provided in Table 1 , the specific data obtained from the candlestick analysis in Table 2 displays the most common candle formations in Candlestick analysis. As can be observed in Table 2, there are 96 bullish and 61 bearish indications in the Jakarta composite index (IHSG) within the observed time period. Hereby, it can be inferred that even though IHSG has 
experienced several critical points in it trading activity, however the general pattern of its price movement has dominated by the bullish indications. In more specific ways, the types of candles appearing in the output of observation are shown as follow.

Table 2. The indication of candlestick formation in the observed date

\begin{tabular}{|c|c|c|c|c|c|}
\hline \multirow{2}{*}{ Candlestick Formation } & \multicolumn{2}{|c|}{ Bullish } & \multirow{2}{*}{ Candlestick Formation } & \multicolumn{2}{|c|}{ Bearish } \\
\hline & Number & $\%$ & & Number & $\%$ \\
\hline Bearish Engulfing & 4 & 4.17 & Bearish Engulfing & 9 & 14.75 \\
\hline Black Opening Marubozu & 9 & 9.38 & Bearish Harami Cross & 1 & 1.64 \\
\hline Bullish Harami & 2 & 2.08 & Black Closing Marubozu & 2 & 3.28 \\
\hline Bullish Mat Hold & 2 & 2.08 & Black Spinning Tops & 1 & 1.64 \\
\hline Dark Cloud Cover & 1 & 1.04 & Dragonfly Doji & 11 & 18.03 \\
\hline Dragonfly Doji & 10 & 10.42 & Hanging Man & 9 & 14.75 \\
\hline Four Price Doji & 11 & 11.46 & Long Black Candle & 1 & 1.64 \\
\hline Gravestone Doji & 3 & 3.13 & Long Legged Doji & 10 & 16.39 \\
\hline Hammer & 6 & 6.25 & Long White Candle & 4 & 6.56 \\
\hline Hanging Man & 9 & 9.38 & Shooting Star & 1 & 1.64 \\
\hline Inverted Hammer & 1 & 1.04 & Three Outside Down & 1 & 1.64 \\
\hline Long Black Candle & 3 & 3.13 & Thrusting & 2 & 3.28 \\
\hline Long Legged Doji & 7 & 7.29 & White Closing Marubozu & 2 & 3.28 \\
\hline Long White Candle & 7 & 7.29 & White Marubozu & 1 & 1.64 \\
\hline Shooting Star & 1 & 1.04 & White Opening Marubozu & 5 & 8.20 \\
\hline Three Outside Down & 4 & 4.17 & White Spinning Tops & 1 & 1.64 \\
\hline Three Outside Up & 4 & 4.17 & & & \\
\hline Two Crows & 1 & 1.04 & & & \\
\hline White Closing Marubozu & 5 & 5.21 & & & \\
\hline White Marubozu & 1 & 1.04 & & & \\
\hline White Opening Marubozu & 4 & 4.17 & & & \\
\hline White Spinning Tops & 1 & 1.04 & & & \\
\hline$\sum$ & 96 & $100 \%$ & $\sum$ & 61 & $100 \%$ \\
\hline
\end{tabular}

Source: The data was proceed (2013)

Refers to the candlestick formation as provided Table 2, it can be seen that most of candle rules are dominated by doji pattern. Doji, denotes as a candlestick formation which is very small with no tail up or tail down and without a body (Duvinage, Mazza \& Petitjean (2013). This circumstance is a bit confusing and of dubiously appearing a huge doubt to the market players. This is due to the number of doji pattern has lead the probability of market driven to the uncertainty. Here, in terms of deciding whether holding or releasing the stock, the market players including investors would be faced by a lot of considerations. Therefore, the predictive power of candlestick analysis is found to be more difficult due to the data-snooping bias. A more comprehensive explanation about the form of candles 
formation relating to its name and indication refers to the study of Marshall, Young \& Cahan (2008) as follow.

Figure 2. Bullish single lines and bearish single lines

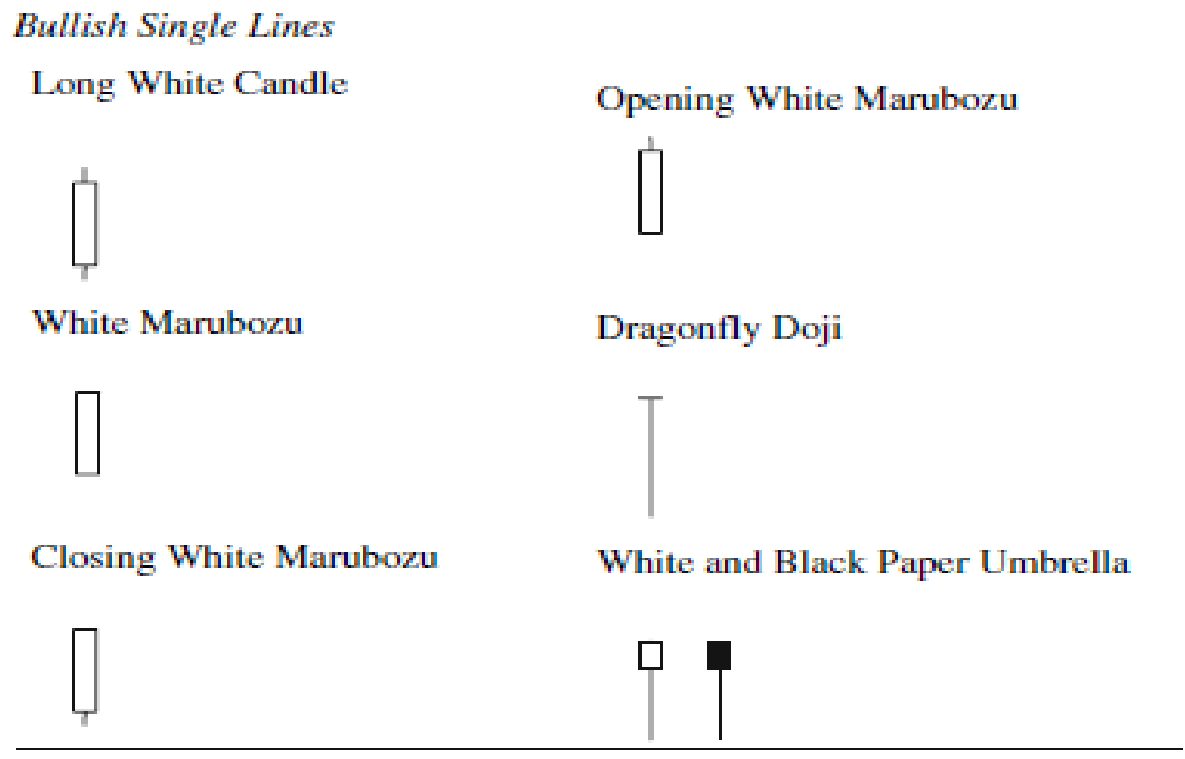

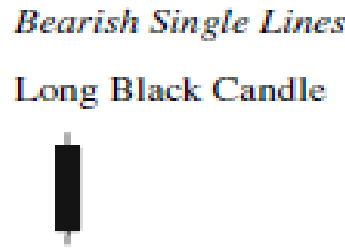

Black Marubozu

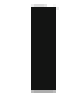

Closing Black Marubozu

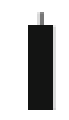

Opening Black Marubozu

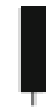

Gravestone Doji

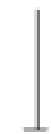

White and Black Shooting Star

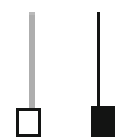

Source: Marshall, Young \& Cahan (2008).

As pointed out by Marshall, Young \& Cahan (2008), single lines commonly take only one day to form. Another type of formation is known as candlestick patterns. This happens when specific single lines appearing on back-to-back days. Also, they report that most of candlestick book suggest candlestick patterns are able to provide more reliable signals than the formation of single lines. However, in 
this case several forms of single lines are assumed to have strong predictive power. In more specific visual description, the bullish and bearish reversal pattern forms are available in Figure 3 and 4 as follow.

Figure 3. Bullish reversal pattern

\section{Bullish Reversal Patterns}

Hammer

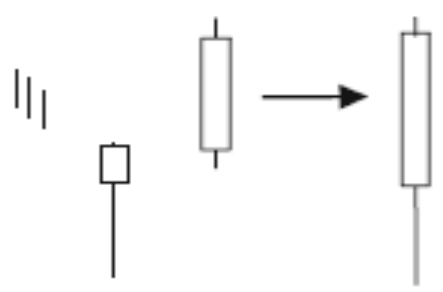

Bullish Engulfing<smiles>C1#CC#C1</smiles><smiles>ClC(Cl)(Cl)Br</smiles>

Piercing Line<smiles>c1ccccc1</smiles><smiles>[3H][3H]</smiles>

Bullish Harami

||<smiles>ClI</smiles>

Three Inside Up

||<smiles>PCl</smiles>

Three Outside Up

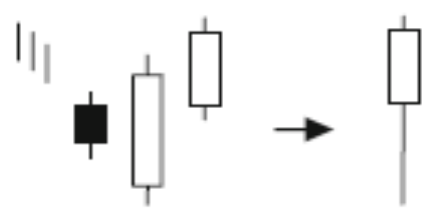

Tweezer Bottom

||

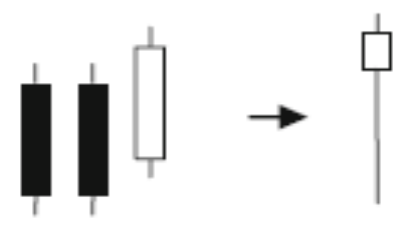

Source: Marshall, Young \& Cahan (2008). 
Figure 4. Bearish reversal pattern

Bearish Reversal Patterns

Hanging Man

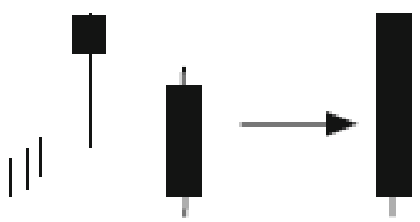

Bearish Engulfing

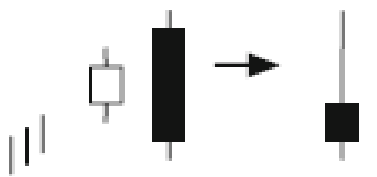

Three Inside Down

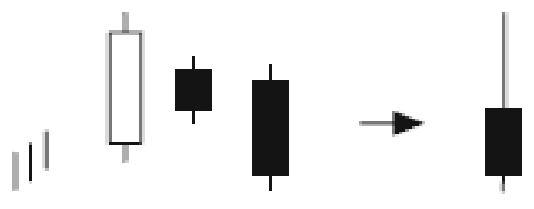

Dark Cloud Cover

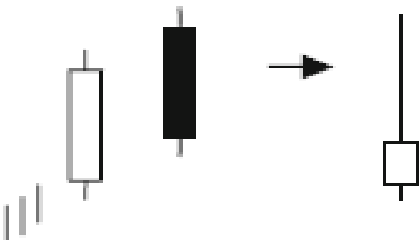

Bearish Harami

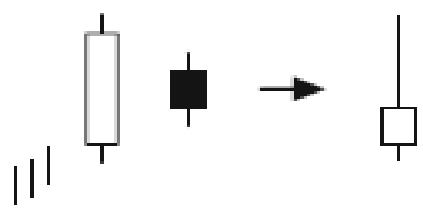

Tweezer Top

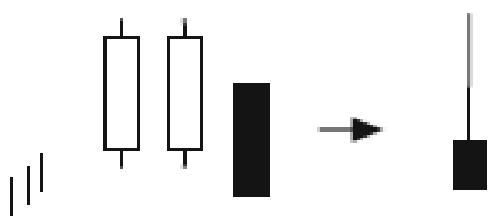

Three Outside Down

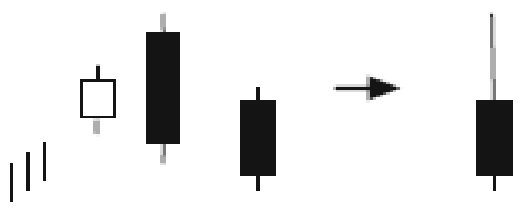

Source: Marshall, Young \& Cahan (2008).

After meticulously observing the specific indications toward the behavior movements of Jakarta composite index, it is necessarily important calculating the proportion between bearish and bullish pattern found in the candlestick analysis. Here, the percentage of bearish indications related to the obtained number of bearish surrogated by various types of candle formations as shown in Table 2 and calculated as follow.

The calculation of Bearish phenomenon $=\frac{\left(\sum \text { Bearish }\right)}{\sum \text { Bullish and Bearish }} \times 100 \%$ 
Calculation of Bearish phenonenon $=\frac{61}{61+96} \times 100 \%$

Percentage of Bearish phenomenon $=38.85 \%$

The percentage of bearish phenomenon occurs in IHSG equal to 38.85 per cent. It can be concluded that the main trends following the pattern of price movements at the index is not bearish, but bullish. This is due to the major percentage of bearish phenomenon that can be detected during the period of observation from 1997 to 2013 is around 38.85 per cent, while 61.15 per cent is the indication of bullish phenomenon which can be seen in the following formula.

The calculation of Bulllish phenomenon $=\frac{\left(\sum \text { Bullish }\right)}{\sum \text { Bullisb and Bearish }} \times 100 \%$

Calculation of Bullish phenomenon $=\frac{96}{96+61} \times 100 \%$

Percentage of Bullish phenomenon $=61.15 \%$

The above findings also confirm similar studies that have been conducted in emerging Asian capital markets. A seminal studies show that candlestick analysis has proven its ability in explaining various phenomena about Bearish or Bullish, both in the capital markets of Taiwan, Japan, India and Indonesia (Goo, Chen \& Chang, 2007; Marshall, Young \& Cahan, 2006, 2008; Hendra, 2008; Usman, 2010; Oktaviani; 2010; Lu \& Shu, 2012; Usman, Nurazi \& Zulkarnain, 2012). The ability of candlestick as a technical analysis tool made it as one of the indicators which is very useful in explaining the patterns of price movements. Nevertheless, the ability of this tool could be enhanced if users add some combination of technical tools. One of technical analysis tools which is compatible on candlestick analysis is MACD (Moving Average Convergen Divergent). The usage of MACD will eventually help the estimation of candlestick output with predicted lines resulted from MACD lines. These lines incline to draw several signs related to the time of investment, which comprise of 5 days, 20 days, and 60 days trading activity.

Moreover, the research of Usman, Nurazi \& Zulkarnain, (2012) on the LQ45 index in Indonesia stock exchange utilized candlestick analysis in observing the price behavior of LQ45 index. Their study employed candlestick analysis for specific time period of observation from 1999 to 2012. They show that the main 
trend found in the observed time is bullish pattern, in which the monthly observation outputs display 57.14 per cent bullish signs while the other 42.85 per cent was in bearish circumstance. This phenomenon is also influenced by the incoming information into the market. As study revealed by Nurazi \& Usman (2015), Nurazi, Kananlua \& Usman (2015) they note that the increasing of information retrieval conducted by the investors inclines to affect the price behavior. Therefore, bad and good news will relatively contribute to the price changes (Nurazi \& Usman, 2015; Nurazi, Santi \& Usman, 20015. Even, in the financial industry, besides the incoming information, fundamental information inclines to be the triggering factors in the returns changes (Nurazi \& Usman, 2016). Therefore, the usage of technical analysis tools in identifying should be followed by the full apprehension of related fundamental information.

Fundamental analysis is based on the analytical review in financial statements that is beneficially proven to the owner of company. It seems that investors who bought the stock solely motivated to receive dividends in long-term horizon of investment. Investors with the motivation of buying certain stock for long-term period incline to wait for the next dividend payments, and exercise their rights in the general meeting of shareholders as owners. The company, which has good fundamental, will prove the long-term benefit to its shareholders. Generally, financial management literature, which is only discussing the fundamental analysis make it worthless for traders who are motivated by the short-term capital gain obtained from the prices changes.

Reciprocally, traders who involved in stock trading activity prefer to short-term profits rather than the long-term profits. The main motive of traders is not dividends, but capital gains (the difference between the opening stock price and the closing stock price). This makes traders tend to optimize the use of software that is employed to forecast the tendency of price movements. For this reason, the simply access to information particularly the ease of use of gadgets, the limitless time of investments, and investment opportunities, become easier to conduct. With respect to the development of information technology, particularly from the aspect of computer programming, technical analysis of candlestick has successfully helped the traders (short-term stock traders, brokers, consultants, 
and financial analysts) in making decisions about "what" to do by observing the movement of stock price, which can be visually observed. Furthermore, in the era of remote trading, candlestick analysis is a kind of reliable tool for traders in conducting their activity. In a simple way, it can tell traders when the indication of bearish, bullish or even price reversal probably starting. Also, the continuation of the price trend can be simply analyzed by the help of candlestick analysis.

\section{CONCLUSION}

According to the results obtained as previously elaborated in the section of results, IHSG has generally shown to experience bearish pattern as its major trends. Also, we find that candlestick analysis remains a continuation of fundamental analysis in analyzing the tendency of price movement. This means that if the fundamental of company is in good performance, it generates more price rises in the price and index trend. Conversely, if the financial fundamental is not good, candlestick analysis results in less price rises in the main price and index trend. Thus it can be proven that the technical analysis is a series of evidence including the company's financial performance.

Moreover, in terms of further research and practices of technical analysis, we also recommend some issues. First, the trader should be carefully in using candlestick analysis tool, particularly when the market is in bearish condition, because bearish market reflects that the macroeconomics is not in conducive circumstance. In bearish condition, traders should be extra carefully due to the use of candlestick analysis will probably produce more doji pattern. This doji formation illustrates the price situation in a confusing circumstance because the price stock is not changing at all. Hereby, candlestick analysis can be combined with Moving Average Convergence and Divergence (MACD) or Stochastic Oscillator tools. By combining the usage of candlestick analysis in the historical data observation, it will bring the user in to a more comprehensive understanding about the flash back of historical data. Thus, the obtained data is able to be employed as a strong technical tool in identifying and explaining either stock or index movements 


\section{REFERENCE}

Brigham, F. E. \& C.M. Ehrhadt, C. M. (2005). Financial Management, Theory and Practice.New York: Mac Graw-Hill.

Brown, J. S. et.al. (1998). The Dow Theory: William Peter Hamilton's Tracks Record Reconsidered. The Journal of Finance. Vol. 53 (4): 1311-1333.

Duvinage, M. et.al. (2013). The intra-day performance of market timing strategies and trading systems based on Japanese candlesticks. Quantitative Finance. Vol. 13 (7): 1059-1070

Fabozzi, F. J. \& C.J. Francis. (1979a). Alpha and Betas Overs Bull and Bear Markets Conditions. The Journal of Finance. Vol. 32 (4): 1093-1099.

Fabozzi, F. J. \& C.J. Francis. (1979b). Mutual Fund Systematic Risk for A Bull and Bear Market: An Empirical Examination. The Journal of Finance. Vol. 34 (5): 1243-1250.

Fama, E. (1991). Efficient Capital Markets. The Journal of Finance. Vol. 46. (5): 15751617.

Fama, E. \& K. French. (1992). The Crosssection of Expected Stock Return. The Journal of Finance. Vol. 47 (2): 427-465.

Fama, E., \& K. French. (1993). Common Risk Factors in the Returns on Bonds and Stocks. The Journal of Finance. Vol. 33 (3): 43-56

Fock, H. J. et.al. (2005). Performance of Candlesticks Analysis on Intra-day Future Data. The Journal of Derivatives. Vol. 4 (4): 28-40.

Hanna, M. (1968). Short Interest: Bullish or Bearish? Comment. The Journal of Finance. Vol. 23(3): 520-523.

Hendra, S. (2008). Candlestick and Its Application In Indonesian Market. Jakarta: Elex Media Komputindo.

Goo, J Y. et.al. (2007). The Application of Japanese Candlestick Trading Strategies in Taiwan. Investment Management and Financial Innovations. Vol. 4 (4): $49-80$

Kavajech, A. K. \& O.R.E. White. (2005). Technical Analysis and Liquidity Provision. The Revie of Financial Studies. Vol. 17 (4): 1043-1071. 
Lu, H. T. \& M. Y. Shiu. (2012). Test for Two Day Candlestick Pattern in The Emerging Equity Market of Taiwan. Emerging Markets Finance and Trade. Vol. 48 (1): 41-57.

Marshall, B. R. et. al. (2008). Are Candlestick Technical Trading Strategies Profitable in The Japanese Equity Market? Review Quantitative Financial Accounting. Vol. 31 (1): 191-207.

Nurazi, R. et.al. (2015). The Effect of Google Trend as Determinant of Return and Liquidity in Indonesian Stock Exchange. Jurnal Pengurusan. Vol. 45: 1-17.

Nurazi, R. et.al. (2015). Tunneling: Evidence from Indonesia Stock Exchange. Asian Academy of Management Journal of Accounting and Finance. Vol. 11 (2): 127-150.

Nurazi, R \& B. Usman. (2015). Public Attention and Financial Information as Determinants of Firms Performance in the Telecommunication Sector. Jurnal Keuangan dan Perbankan. Vol. 19 (2): 235-251.

Nurazi, R \& B. Usman. (2016). Bank Stock Returns in Responding the Contribution of Fundamental and Macroeconomics Effects. Journal of Economics and Policy. Vol. 9 (1): 134-149.

Oktaviani, Y. (2010). Analisis Bearish dan Bullish Saham PT Telekomunikasi Indonesia dan PT Plantation Indonesia pada Studi kasus 1 November 2008 sampai 1 November 2009. Working Paper. Faculty of Economics University of Bengkulu.

Pring, M, (2002). Candlesticks Explained. New York: Mac Graw-Hill.

Seneca, J. J. (1967). Short Interest: Bearish or Bullish? The Jurnal of Finance. Vol. 22 (1): 67-70.

Seneca, J. J. (1968). Short Interest: Bearish or Bullish? Reply. The Jurnal of Finance. Vol. 23 (3): 524-527.

Shiu, M. Y. \& H.T. Lu. (2011). Pintpoint and Synergistic Trading Strategies of Candlesticks. International Journal of Economic and Finance. Vol. 3 (1): 234-244.

Tandelilin, E. (2010). Portofolio dan Investasi: Teori dan Aplikasinya. Yogyakarta. Kanisius 
Usman, B. (2010). Analisis Bearish Versus Bullish Saham PT Bakrie Telecom Tbk. Pada Interval Waktu 1 Januari sampai dengan 31 Desember 2010, dengan menggunakan Analisis Candlestick. Working Paper. Faculty of Economics University of Bengkulu.

Usman, B., \& E. Tandelilin. (2014). Internet Search Traffic and Its Influence on Liquidity and Returns of Indonesia Stocks: An Empirical Study. Journal of Indonesian Economy and Business. Vol. 29 (3): 203-221

Usman, B. (2013). The Analysis of Bearish and Bullish by Using Candlestick Analysis Evidence of Jakarta Composite Index (1997-2013). The 14th Malaysia Indonesia Conference on Economics, Management and Accounting. Institute Agricultural Bogor.

Usman, B. et.al. (2012). Analisis Akurasi Bearish Versus Bullish Menggunakan Candlestick Analysis: Studi Empiris terhadap Indeks Saham LQ45 (19992012). Management Insight. Vol. 7 (2): 154-170.

Varadharajan, P. \& P. Vikkaraman. (2011). Efectiveness of Technical Analysis Using Candlestick Chart for Selection of Equity Stock In Indian Capital Capital Market. The Journal Contemporary Management Research. Vol. 25 (1): 1223.

Zulkarnain, I. (2012). Akurasi Pemodelan Harga Saham Dengan Model ARIMA dan Kombinasi Main Chart+Ichimoku Chart. Management Insight. Vol. 7 (1): 59-70. 